This item was submitted to Loughborough's Research Repository by the author.

Items in Figshare are protected by copyright, with all rights reserved, unless otherwise indicated.

\title{
Between Russia and Estonia: narratives of place in a new borderland
}

PLEASE CITE THE PUBLISHED VERSION

http://dx.doi.org/10.1080/00905992.2013.774341

PUBLISHER

(C) Taylor \& Francis

VERSION

AM (Accepted Manuscript)

\section{PUBLISHER STATEMENT}

This work is made available according to the conditions of the Creative Commons Attribution-NonCommercialNoDerivatives 4.0 International (CC BY-NC-ND 4.0) licence. Full details of this licence are available at: https://creativecommons.org/licenses/by-nc-nd/4.0/

\section{LICENCE}

CC BY-NC-ND 4.0

\section{REPOSITORY RECORD}

Pfoser, Alena. 2014. "Between Russia and Estonia: Narratives of Place in a New Borderland". Loughborough University. https://hdl.handle.net/2134/19105. 
Between Russia and Estonia: Narratives of Place in a new Borderland Alena Pfoser ${ }^{\mathrm{a}}$

${ }^{a}$ Department of Social Sciences, Loughborough University, Loughborough, UK

Alena Pfoser. Department of Social Sciences, Loughborough University,

Loughborough, Leicestershire, UK, LE11 3TU. Email: A.Pfoser@lboro.ac.uk. 


\section{Between Russia and Estonia: Narratives of Place in a new Borderland}

The Russian-Estonian border has undergone radical changes in the past two decades - from an integrated borderland between two Soviet republics to a border between nation-states and the new EU external border. Until the present day it is a discursive battlefield that reflects the difficult relations between Russia and Estonia after the restoration of Estonia's independence. While much research has concentrated on antagonistic projects of identity politics and state-building from a from a top-down perspective, this paper asks how people living in the borderland make sense of the place they live in and negotiate shifts in the symbolic landscapes. Based on life-story narratives of Russian-speakers, it analyzes different ways of narrating and framing place and argues for a consideration of the plurality and ambivalences of place-making projects on the ground. Furthermore, it argues for a more balanced account of continuity and discontinuity in memory narratives by taking into account how the socialist past continues to be meaningful in the present. As the interviews show, memories of the socialist past are used for constructing belonging in the present both by countering and by reproducing national narratives of boundedness.

Keywords: place; memory; border; Russia; Estonia; Russian-speaking minority.

The end of the Cold War and the break-up of the Soviet Union led to a radical reconfiguration of geopolitical space. This was accompanied by shifting boundaries, swift nationalization and region-building processes. As Eastern European states oriented themselves westwards, new symbolic boundaries have been drawn and have been legitimized with the help of new historical narratives and memories. Many studies have analyzed the linkages between collective memory and nation-state building in Eastern Europe and the former Soviet Union. ${ }^{1}$ They have explored how new political elites rescripted the past in order to legitimize their rule, to speed up the transition to democracy and create social cohesion in times of economic hardships. Furthermore, they have pointed to the emergence of new divisions arising out of clashes between the nationalized historical narratives of the new states, particularly in relation to the legacy 
of communism and interpretations of WWII.

Nation-building processes are always accompanied by ambivalences, contestations and disjunctures between scales and social groups. Particularly in recent works, scholars have argued that we should pay more attention to how nationalizing or nationalistic versions of the past are challenged by alternate narratives and commemorative practices at different scales. At the supranational level they point to influence of actors like the EU (Malksöö, Onken “The Baltic States”), and at the other end emphasize the negotiation of national narratives at local and regional levels (Ochman; Czaplicka, Gelazis and Ruble; Batt and Wolczuk).

This article builds upon these studies and analyzes how national narratives have been negotiated at the local level. In doing that, it links the political transformation back to people's personal memories and experiences by concentrating on their meaningmaking activities in everyday life. A focus on personal memories can furthermore give a more balanced account of continuity and change in the region. Concentrating on elitebased and instrumentalist memory projects, much of the literature has stressed discontinuity, the erasure of the socialist past and the creation of new symbols and narratives. The renaming of streets, the erection of new monuments and the removal of old ones have offered multiple examples for studies exploring the remaking of symbolic space after the fall of the Iron Curtain. Following Light and Young's call to pay more attention to the "persistence of state-socialist landscapes" and the "complex and hybrid post-socialist memory-scapes and contested spaces of the nation” (Light and Young 1475), I will explore how the socialist past continues to matter in personal memories and in meanings attached to places.

Borderlands are particularly good sites for analyzing the ambivalences of nationbuilding processes. Not only are they sites where the forging of national identities 
acquires great intensity but are also locations where alternative constructions of self and place can be found (Newman and Paasi; Baud and Schendel; Sahlins). Especially in the borderlands of nationalizing states, there is a tension between the state's attempt to create fixity and clarity in space and the lived realities of people in which memories of a time without a border are still vivid and social and symbolic ties continue to stretch to personally significant people and places on "the other side". This article takes the Russian-Estonian borderland as a case study. It focuses on the Estonian border town of Narva, populated almost exclusively by Russian-speakers ${ }^{2}$. In comparison to ethnic Estonians, Russian-speakers living in Estonia have been confronted with a greater need to adjust their identities and to reconsider past experiences due to significant asymmetries in how the transition was organised. ${ }^{3}$ The narratives of Russian-speakers thus serve particularly well to illustrate how people in their everyday life negotiate their understandings of past and present, and to show tensions and contradictions involved in negotiating belonging on the margins of the nation-state. Analyzing their life-story narratives, I will point to alternative ways of remembering the past and making place, which do not fit neatly into the new national narratives. The following sections first present a discussion of literature on place and memory laying out the theoretical basis for the analysis, then go on to provide an overview of the historical context and previous literature in the field, and finally lay out the empirical results of the study.

\section{Place and memory: theoretical considerations}

The spatial turn in the social sciences has raised awareness of the constructedness of places as “meaningful locations” (Cresswell 7). While place had long been understood as a mere context and backdrop for social life, scholars have now pointed to its social production both through the creation of material environments and their investments with cultural meaning (Gieryn; Soja). Memory plays an important role in this process - 
it is through memories that places acquire symbolic meaning and are linked to imagined cultural and political communities (Halbwachs). Despite the multiple and changing meanings places can acquire, there are attempts to fix authoritative meanings of the past in places. Anthony Smith has pointed to the territorialization of memory in the process of nation-building. The inscription of memories in place turns particular lands into what he calls “ethnoscapes”, i.e. historical homelands for particular ethnic groups (Smith). Drawing upon historical myths and metaphors of "rootedness" in "the national soil" relations between people and place are naturalized and a "geography of belonging" is created (Hodgkin and Radstone 169; Till).

Symbolic representations of places are certainly powerful in shaping people's understanding of places. However, these are not simply imposed on an empty space but are interpreted, appropriated and contested at multiple scales and sites. There is no uniform way of imagining and remembering place but a multiplicity of "intersecting place-making projects” (Gille and Ó Riain 278) which are differently aligned with power. ${ }^{4}$ Cities and regions, for example, can acquire multiple meanings and become sites for competing claims of belonging and the "cultural struggle over territory, which necessarily involves overlapping memories, narratives, and physical structures” (Said 182). While much of the existing studies on place and memory have concentrated on cultural representations of place and meanings of monuments, I will analyze the construction of place in personal narratives. This draws upon an understanding of place which is linked to people's everyday lives and their embeddedness in larger discourses and systems of representations. As scholars working in the field of memory studies have argued, in order to tell us something about the social relevance of representations, it is necessary to consider how they matter for people: “...the crucial issue in the history of memory is not how a past is represented but why it was received or rejected" (Confino 
1390). To analyze personal memories in relation to public representations does not mean to oppose "abstract discourses” to "authentic place-based memories” but to understand how narratives of the national past work with and against individual memories. Authors working with an intersubjective approach of memory have stressed that memories are always both “embedded” and “embodied” - they are embedded in larger meaning frameworks which can be adopted, reworked and rejected, while at the same time being linked to a "unique set of past experiences and a unique history of interpreting and inscribing experiences” (Prager 110; Misztal). It is to this quality of memory that Paasi refers to in his work on the Finnish-Russian border when he writes that: "interpretations of socio-spatial structures... are bound to the experiences of one's life-world and spatial life history” (Paasi 207).

Considering the role of experiences for memory narratives opens up the possibility to see memories not merely as shaped by the present. Memory certainly involves a reconstruction; images of the past are not simply stored in people's minds but change according to present conceptions and interests. However, as Schudson has pointed out, there are "limits to the power of actors in the present to remake the past according to their own interests“ (Schudson 4). Although the meaning of an event or a place can change over time it is usually not completely made up. A dialectical conception of the present and the past means that not only the present shapes the recollections of the past but also that the past has an impact on the present: memories provide a framework for understanding what is going on in the "here and now"; the present is interpreted based on past experiences. These constraints in remaking the past are especially relevant when it comes to accounting for internal inconsistencies and disjunctures in nation-building processes. 


\section{Drawing the boundary between Russia and Estonia}

From a macro-perspective, the border between Estonia and Russia has been characterized as a discursive battlefield shaped by polarized imaginations of political space (Berg and Ehin; Kuus; Lehti and Smith). It has experienced dramatic changes in the past 20 years shifting from being an internal border within the USSR to becoming an international border between nation-states and the new EU external border. After the restoration of its independence, Estonia has stressed its difference to Russia and the border has been represented as a line between two civilizations - the East and the West. Estonia's priority has been to face westward, to make the border with Russia as firm as possible while other borders with EU members became more permeable.

Memory politics has been identified as one of the important fields for symbolic boundary drawing between Estonia and Russia (Kattago; Berg and Ehin; Hackmann and Lehti; Brüggemann and Kasekamp; Onken “The Baltic States”). Authors have drawn attention to the politicized and polarized character of memories of WWII and the communist regimes. They have studied spectacular memory events in which such antagonistic memories crystallize - most notably the conflict around relocation of the Bronze Soldier in Tallinn in 2007 (for example Kattago; Brüggemann and Kasekamp; Lehti, Jutila and Jokisipilä). For Estonia, the “memory war” with Russia has both external and internal dimensions. The anticommunist narratives of suffering and resistance in Estonia mark a break to the Soviet past and a distance to Russia. At the same time, they have been experienced as exclusionary and polarizing within Estonian society by those who do not fit into the alleged community of victims valorized in the new national memory narratives. Consequently, rather than remembering a shared experience of communism, Estonia has become "a society that is characterized by divisions on ethnic lines and historic memory” (Brüggemann and Kasekamp, 427). 
While ethnic divisions in memory certainly matter in present-day Estonia, the problem with some of the research is that it takes the oppositional narratives for granted and juxtaposes them as stable positions regarding the past. In these accounts, Russians remember war heroism and liberation while Estonians remember national suffering. However, this duality is too static as it leaves out the ways in which Estonian national narratives might transform Russian-speakers' ways of making sense of the past. More significantly, the assumption of a divided memory cannot account for the plurality of memories on the socialist past which can be found within Estonian society. A dualistic account cannot provide space for the examination of ambivalences and divergent memories that exceed the binary ethnic categories. While it is true that in conflicts over the past, memories tend to become polarized and differentiated accounts tend to get lost from view - shall this limit our analysis only to those cases? It is all the more important in this situation to develop a framework which can allow space for documenting the complexities and ambivalences of personal remembering. ${ }^{5}$

In this article the narratives of Russian-speaking residents of the Estonian border town of Narva serve as an empirical example to demonstrate the complexities of remembering and “making place” between Estonia and Russia. Present-day Narva is an industrial town with a population constituted by over 95\% of Russian-speakers. Narva’s Russian-speaking residents are situated literally and symbolically at the margins of the new national memory projects (on the marginalization of Russian-speakers in the “memory wars” cf. Lehti, Jutila and Jokisipilä). They moved from Russia and other Soviet Republics to Narva after Estonia had been incorporated into the Soviet Union for the second time. Their sense of place has been shaped by memories of Soviet and postSoviet times connected to personal experiences of post-war reconstruction and industrialization which turned Narva into an industrial town with typically Soviet 
architecture. While most of them do not consider moving back to Russia, they find themselves excluded from the Estonian national memory community.

In my analysis I will focus on their personal memories of living in this place. However, it is clear that Narva has been endowed with multiple and often conflicting meanings. In the past Narva experienced changing sovereignties under Danish, Livonian, Swedish and Russian rule and has therefore often been regarded as a contested borderland between Protestantism and Orthodox faith, "Western” or Russian influence. In its recent history, the destruction of the town during WWII marks a watershed. In 1944, Narva was almost completely destroyed by Soviet bombardments. In place of the old town, which used to be famous for its Baroque architecture, a new one was built that differed radically in the composition of its population as well as in its architectural appearance (Brüggemann "Wiederaufbau”; Weiss-Wendt). The former population, who had been evacuated by the German occupants, was regarded suspiciously by the new Soviet rulers and was not allowed to return to Narva. The reconstruction of Narva was undertaken by newcomers from Russia and other parts of the Soviet Union as well as by prisoners of war, who in the early post-war years amounted for large numbers of the work force (Mertelsmann 110). In the late 1980s, discussions about the status of Narva within Estonia gained momentum and “integration” emerged as the keyword in discussions about the "Russian enclave”. With the break-down of Soviet rule, Estonian cultural elites and historians initiated some rather hesitant attempts at rewriting the local memoryscape by erecting new monuments, organizing new commemorative activities and publishing historical literature with a focus on the pre-war history of the town (on some of these monuments and activities cf. Burch and Smith; Kaiser and Nikiforova). ${ }^{6}$ These attempts to Estonianize (and Europeanize) Narva have only been partly successful; in the eyes of most Estonian Narva was - and still is - considered to be "not quite 
Estonian” and remains a symbol of the loss and destruction brought by the Soviet occupation. Furthermore, Narva is seen to embody, at least potentially, a security threat for the nation-state due to an autonomist movement at the beginning of the 1990s and the persisting fear that "local inhabitants might look eastwards towards Moscow rather than westwards towards Tallinn” (Burch and Smith 920). The high unemployment, social problems like high HIV infection rates and criminality as well as the continuous depopulation since the restoration of Estonian independence add further to the negative image. However, to draw a fuller picture of the transformation of the borderland, the experiences and memory narratives of Narva's residents need to be included in the analysis. How have the shifting symbolic geographies and new historical narratives shaped their perception of place?

In the following sections I will outline two key narratives of place which people use when narrating the past. The first frames Narva as a Soviet place and is linked to narratives of connections, progress and industrialization that were central to the Soviet modernization project. The second constructs Narva as an Estonian place and draws upon images of Estonian distinctiveness and superiority. Both these seemingly oppositional place narratives derive from the memories of the socialist past and exist simultaneously in people's accounts. While they show the continuing relevance of official Soviet narratives in people's place identities, they cannot be fitted back into a framework which simply opposes them to Estonian nationalist narratives. Instead I argue that their engagement with Narva's past has to be seen as an attempt to construct belonging by both countering and reproducing national narratives of boundedness.

My analysis builds upon five months of ethnographic fieldwork in Narva and the neighboring town of Ivangorod on the Russian side of the border over the past two years, the bulk of it being done between September 2011 and January 2012. Along with 
archival research and participant observations, I conducted 59 life-story interviews with people living on both sides of the border in order to get insights in the dynamics of remembering and place-making in the borderland.. The interviews were semi-structured with large narrative parts aimed to elicit stories.In the first part,people were asked to tell their life-stories. The biographical narration was followed by more specific questions on their sense of place, cross-border contacts and their perception of changes in the second part. The interviews took between 50 and 210 minutes. The following analysis will limit itself to accounts of Russian-speaking inhabitants of Narva who came of age before the break-up of the Soviet Union. ${ }^{7}$ Altogether 15 interviews were included in the analysis. The interviews were selected on the basis that participants could draw upon their own experiences of the socialist past. In comparison to this group, interviews conducted with the post-Soviet generation differed significantly and showed the emergence of "new cultural templates” and signs of Europeanization (similar generational patterns were observed in Vihalemm's and Kalmus' quantitative study).

\section{Remembering Narva as a Soviet place}

“After the war there was nothing here. Soviet Union built everything, all the factories were built by the Soviet Union. The only thing that Estonia did, was to sell these

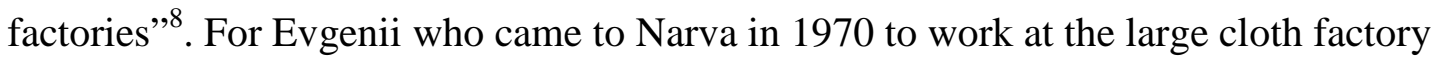
Krenholm, the history of Narva consisted of its rise with the Soviet post-war reconstruction efforts and its fall after the restoration of Estonia's independence. Evgenii was born in Ukraine and had worked on construction sites in several Ukrainian towns before moving to Narva. It was this Soviet past that had shaped Evgenii's sense of place and self. "I am a Soviet man” he declared at the end of the interview. For him being a Soviet man meant to be shaped by Soviet multiculturalism and the experiences of industrial work at the Krenholm factory. 
While not many of my interviewees derived their personal identity as explicitly as Evgenii from the Soviet past, their memories of Narva were to a great extent linked to this period. They had perceived Narva as being part of one large Soviet space shaped by the efforts of post-war reconstruction, industrial work and an atmosphere of friendship. In the following section, I will outline the experiences which made Narva a typically Soviet place for my interviewees and consider them in relation to the present. As demonstrated by Evgenii's complaint that Estonia did not do anything for Narva apart from selling (and consequently destroying) the factories, memories have to be contextualized in relation to people's present social position.

Nadezhda moved to Narva in 1982 after having finished school in a Karelian village. She remembered that she had wanted to "live a better life" in a city and moving to Narva was just one of several options she had had:

\begin{abstract}
After school, when you had to choose a profession, there were such booklets... the Soviet Union was large and there we could find the cities where one could get a profession, where you were provided accommodation and where not. And we chose by trial and error. Oh! This, this and that - we flipped through it. We could have chosen to study anywhere. We didn't go to Narva, because we wanted to go only there. We could have ended up in any town. In any town in the Soviet Union. ${ }^{9}$
\end{abstract}

This quotation demonstrates the success of the Soviet ideology in nurturing an imagination of the Soviet Union as one shared space. For Nadezhda it did not matter that Narva was on the territory of the Estonian SSR. It was just one node in the wider Soviet space of opportunity within which she, like many other Russians, obtained professional education and found a work place. It also became a starting point for her travels. For several years she went home to visit her parents every month; experiencing free mobility and travelling to different places in the USSR became her favorite holiday 
activity.

Other interviewees also referred to the Soviet Union as a common space characterized by connections and standardization of housing, a shared ideology and Russian language. Russian had become the lingua franca in post-war Narva and rendered the town even more similar to the places people had lived in before. Elena, who came with her husband from Belorus, remembered:

\begin{abstract}
We were sent to Narva (after finishing education) and we came here, of course, it was interesting in a different... but during Soviet times it wasn't scary, we came here and spoke Russian. Everybody asked 'how is it that you're going to Estonia?' but we came here and here everybody was Russian (...) it was as if we had been living here all the time. ${ }^{10}$
\end{abstract}

Despite her (or other people's) expectations that she would encounter difference in Estonia, the Russian language and the presence of other Russians offered a familiar and reassuring environment.

In particular it was the large industrial enterprises, among them the Krenholm cloth manufacture, the military factory Balti TS and two electric power plants that structured people's experience of place and that were the subject of vivid recollections in several interviewees. Svetlana, who moved to Narva at the age of 27, focused her whole life-story narration on the Krenholm manufacture and recounted with great detail the technical process and the collective experiences in the factory:

I was working for more than 30 years at Krenholm. I worked during the day shift. We were busy with machine maintenance because the machines required service. We worked in the spinning collective. At the enterprise, there was also the spinning collective, the weavers, and then there were the textile, the finishing and the clothing manufactures.... We've grown up there, we've found friends there. It was a real family. We went to work in the morning. When there was something to celebrate, for example, a birthday, we brought sweets and a cake, during lunchtime. When somebody was mourning, somebody had died, we collected money and they 
let us go to the cemetery to stand by. When somebody had a problem, of course, we supported each other, we were a real family. Even if we don't see each other so often now, when we meet, we hug each other and ...start to remember, how we were working together, which efforts we made, and how hard it was. ${ }^{11}$

Svetlana described her three decades of work at the factory as stable experience in which the individual and the collective were closely interconnected. Working at the factory appeared as "a whole way of life"; the labor collective not only worked together but shared joys and grief equally. Comparisons of the labor collective with a family and a circle of friends were also prevalent in other interviews and demonstrated the strong identification with the factory (and a nostalgic yearning for the loss of this collective way of life). In some accounts, the atmosphere of friendship at the factory extended to a friendship between nationalities. Evgenii, who worked together with people from different nationalities, among them Estonians, described his work experience in the following way: "We were friends, everything was alright. No nationalism. Nothing. We just knew one thing... maybe that's because we were brought up in the Soviet Union, we respected each other."12

The significance of the factory in everyday social life was not only linked to a strong personal identification with the labor collective but also to the fact that state protection and benefits were mediated through the workplace. This created the feeling that the factory and the state cared for its people (Ashwin). Working at the factory included cultural activities like singing in a choir and participating in sports competitions, group holidays and recreation at sanatoriums. In comparison with these narratives of the good life under socialism which clearly struck a nostalgic tone, negative aspects like the hard physical work, health issues or job hazards tended to be downplayed. In Svetlana's account, for example, the fact that she had to observe safety 
measures for her work was not used to prove the potential risk involved in the work but to show that the factory actually cared for the workers.

Similarly, the difficult housing situation - the fact that some people had to wait for several years to obtain a flat of their own - was recounted in most narratives as being normal. Life in the dorms, despite the lack of living space, was characterized in terms of friendship and mutual support. As most of the houses had been destroyed during WWII, new ones had to be erected to provide the growing community of workers with the necessary living space. ${ }^{13}$ In many accounts, Narva was therefore perceived as a town under construction.

I remember the time when we obtained our first flat, this flat was on K. street. And behind our house there was house number 40 and a big field. There was grass; goats, sheep grazed there. And when both power plants were working, everything was alright; houses were being built like mushrooms after the rain, within a couple of months a new house appeared. ${ }^{14}$

Stories of construction were recounted on the one hand to convey a sense of progress and modernity and on the other hand were used to provide a sense of knowing the town and feeling at home. The recollections of life in Soviet Narva drew on many elements of official Soviet narratives of industrialization and progress in the Baltic States. However, people's memories were not simple adoptions of this discourse but were linked to concrete experiences of local life and home and used reflexively - in relation to present day Estonian national narratives.

Misztal reminds us that the process of remembering "refers to both telling a story about the past and telling a story about the past's relation to the present” (Misztal 70). In most recollections, people made a clear distinction between the Soviet and postSoviet period. This was connected to a personal and/or collective experience of decline. ${ }^{15}$ Whilst the sense of living in an important center of industrial production 
shaped much of people's sense of place in the past, this was contrasted with a sense of loss and marginalization in the present documented in sociological studies on the Russian-speaking minority. ${ }^{16}$ My interviewees recounted experiences and narratives of decline in stories of losing their workplace, being denied automatic citizenship or seeing their friends move away. Although younger interviewees had managed to establish new connections, a general sense of having become peripheral was dominant in almost all of the interviews. In one of the accounts, Anton, an entrepreneur in his mid-forties, compared present-day Narva to an "appendix", a useless bodily organ, for Estonia: “The city is going to ruin (rasrushaetsia), too many people have left."17 Due to nationalization and the subsequent deindustrialization, Narva has become side-lined within Estonia and this was often linked to feelings of personal marginalization. What reinforced these feelings was a sense that their belonging in place was being questioned. Having lived and worked in Narva for many years, people were suddenly confronted with the feeling of being no longer wanted in Estonia. As Mariya, an engineer, who went to do unskilled labor in the UK after she lost her job at one of the big factories, stated:

\footnotetext{
Those years, you can't throw them away; you can't throw them out of your life, out of history, out of everything. The people who were born here, who have grown up here, this is their homeland (rodina), isn't it? There (in the UK), of course, when you go there, you feel like in a different country. But here we did feel like in our own country. ... You know, during Soviet times not everything was as bad as it is presented now. There was much more and it was much better. I can understand the national self-consciousness but... how did it turn out?! Everything was destroyed and now ${ }^{18}$
}

Mariya's statement clearly demonstrates the two ways memories of the Soviet past are related to the present. Firstly, she uses the past reflexively to criticize the present. While she does not question Estonian independence, she makes use of the past to criticize the form of nation-building which she perceives as being destructive. Secondly, she uses the 
past to construct belonging by arguing that living in a place for a long time rendered it into a homeland. The sense of the fragility of this belonging in the present is however clearly evident.

As I argued earlier, personal memories linked to places can help to account for disjunctures in nation-building processes. Mariya's account as well as the accounts of other informants shows how the past serves both as a reference point for the critique of the present and as a set of experiences which have cumulatively formed people's sense of place and self. Contradictory logics of making place become apparent in this context: the logics of national narratives of rupture and discontinuity which displace Russianspeakers on the one hand, and the embodied experiences of having lived in Narva for many years and the feeling of one's own place on the other. My interviewees remembered the socialist past relating to and countering the national narratives and used their memories to reclaim belonging in the present.

In particular, the Estonian discourse of the Soviet period as “occupation” and the Soviet settlers as “occupants” was picked up by many of my interlocutors. The label of “occupant” most clearly put the status of the Russian-speakers in Estonia under question and excluded them from the nation, constructing them as part of an oppressive alien power. My interviewees used different rhetorical strategies to counter it: some reflected upon the peaceful coexistence between Russians and Estonians in Narva ("why do they hate us Russians?”, “we didn't suppress them”) ${ }^{19}$. Others presented themselves as victims of external circumstances ("I was never taught Estonian language in school”) ${ }^{20}$ or stressed the individual and collective efforts in the reconstruction of Estonia after the war. The ways of "talking back" demonstrated feelings of insecurity and indignation among Russian-speakers as well as the persistence of Soviet imaginations of Russians as "bigger brothers" and helpful colonizers of Estonia, which could be mobilized to 
justify belonging. Sergei, who came to Estonia as a child, had been working in one of the big power plants until his forced early retirement:

I was working here for twenty-thirty years, I invested money in this republic, I developed it, the industries were developed, God forbid. That's how it was. ... I have a flat, a garage, everything, all of my children are here. Why should I leave? Let's calculate: How much money did I put in your republic and then return me the money. Then people start to get angry. I say: Wait, why are you like this? Which right do you have to tell me that I should leave? ${ }^{21}$

Sergei connects his individual life-story with the collective story of the post-war reconstruction and industrialization of Estonia. By emphasizing his contribution, he claims recognition of his work and constructs himself as a citizen who has an equal right to live in Estonia.

Consequently, remembering Narva as a Soviet place can be understood as a means to counter the devaluation of the Soviet past, during which the city was reconstructed and became wealthy. People experienced this as a personally meaningful time in their life-stories, a time which had been constitutive for their sense of place and feelings of belonging. Narrating themselves as part of Narva is a form of engaging with nationalist politics and of claiming recognition in the national (Estonian) memoryscape.

\section{Remembering Narva as an Estonian place}

As indicated earlier, the post-independence nationalization of memory in Estonia has also left its impact on the local memoryscape. Some political and cultural initiatives were aimed at restoring the memory of "Old Narva”, the pre-war town which was often idealized as the true and authentic Narva in contrast to the modernist Soviet architecture. While the pre-war past did not play an important role in the Russian-speakers' personal accounts, many interviewees did frame Narva as an Estonian place drawing on 
memories of the Soviet and post-Soviet past. Estonianness, in their perception, was not something which had to be sought in the pre-war past but had always been integral to their local experiences of place. People remembered Narva not only as a place with connections and similarities to other places in the Soviet Union, but also engaged in boundary-drawing, referring to symbolic differences and national differences linked to Narva's geographical location in Estonia. Experiences and perceptions of difference dated back to Soviet times. Although the border between the Estonian and the Russian Soviet Republics did not materialize until the early 1990s, the distinction between Estonia and Russia was experienced and narrated in terms of administration, consumer culture as well as on a symbolic level as in imaginations of distinct, "Estonian” cultural traits that had become part of their own identity. This alternative narrative of place - as Estonian - is not contradicting the Soviet one but could be found alongside it in many biographical accounts. Although in certain accounts one narrative predominated, in most cases the interviewees remembered both the similarities and past connections which constituted Narva as a Soviet place and the differences and advantages of life which marked it as being Estonian.

Narratives of difference were connected to multiple experiences but were usually linked to biographical encounters with places and people in Russia or other Soviet republics. When people went back to visit their places of origin, served in the army, worked or obtained professional education in other places, they often reported an experience of difference. Ol'ga, for example, who moved together with her parents from a village in Belorus to Narva in 1960 remembered her first visit in her home village the following way:

In 72, we went home (na rodinu). We went on holidays, my husband and me and the older son, he was already five years old. There was this moment when (I became aware of) ... how we were living here and how they were living there. 
Here we both had been working already for some years... We weren’t living worse than others. It was normal for that time. But there, there wasn't any milk at all, no sausages, no meat. We were surprised to see this but well... we had heard about this before, and we had taken a lot of food with us. I remember that we got up at five or six in the morning only to get some milk (in the village). Yes.

I: And did you have to stand in a line?

O: Yes. If you were late, there wasn't anything left. Because there wasn't enough for everybody. Well, for us this was of course (surprising)... The shops there were empty, the kiosks were empty, and here we always had everything. ${ }^{22}$

In direct comparison with places of origin, differences in living-standards became evident: while in Narva, Ol'ga and her husband had an average living-standard ${ }^{23}$ going back to her home village she became clearly aware of what she had achieved in Narva. Recollections of the differences in living standards and levels of access to commodities between Estonia and other Soviet Republics were quite common among my interviewees. Especially dairy products and meat but also textiles from the Krenholm manufacture and the famous Vana Tallinn liquor were commonly mentioned as indicators of prosperity. Svetlana who first lived in Ivangorod $^{24}$ before she succeeded in finding work in Narva interpreted the differences between Narva and much smaller Ivangorod as differences between the two republics:

I came here to the provinical town of Ivangorod. But as I received a room in Ivangorod, my eyes were all the time sparkling on Narva. I wanted to move to Estonia.

She remembered going to Narva on multiple occasions while still living in Ivangorod:

Here was a dairy plant, a meat factory; we took everything with us to Ivangorod. I always liked the ideal cleanness here. The bushes were cut. Everything was somehow different. (In Ivangorod) we always had queues, but here were enough shops, already some shops with self-service. We still had counters. Here were more intellectuals (intellegentnye). Also here were more events, the day of the city, parades on first of May. ${ }^{25}$ 
These excerpts demonstrate the local appropriation of discourses of Estonianness and Westernness as signifying wealth, culturedness and modernity opposed to scarcity and backwardness in Russia. The vision of the Baltic region as "Western" dates back to Tsarist times, when Russian elites wanted to "europeanize” the empire and saw the Baltic States as a model to follow. Their distinct historical heritage and culture as well their developed consumer culture made the Baltic states also during Soviet times "our West” for many Russians (Zubkova; Brüggemann “Enemy’s Outpost”). Contrary to the assumed uniformity of the Soviet Union sharing an ideology, a common constitution and economic system, differences between places and republics were reflected in people's narratives of place. One interviewee born in Narva told me that it was when serving in the army that he for the first time experienced the difference in living standards within the Soviet Union:

Back then I understood that everything is different. We lived better here... we had a good agriculture and that's why we didn't have a problem with food supply. We had everything on our own, everything. ${ }^{26}$

Telling stories about places and relationships to place are integral to narratives of personal and collective identities. "The meanings attached to places imply identities for the people of a particular place“ (Taylor 251). This is clearly in evidence in the recollections of Russian-speakers in Narva; their narratives of place and self were related: the experience of cultural differences between Narva and their place of origin was incorporated to people's self-understandings. People who were born in Narva told stories about the distinct cultural environment in which they had grown up. And those who moved to Narva from other Soviet Republics often referred to an adaptation process through which they became more Estonian or Western - speaking differently ${ }^{27}$, 
becoming quieter and more ordered ${ }^{28}$ and generally more cultured ${ }^{29}$. Tamara who moved to Narva from Ukraine stated:

For me Estonia became like a second home (rodina) because my children were born here and then, I wouldn't even think to move to another country. When I go to Ukraine, I already feel like a stranger there. Here is a different mentality, a different life-style. I am not used to that life anymore. When I go there, I can feel that very clearly, that I am different. And my classmates and relatives too, they see that I am different... Here people are calmer, less emotional, more reserved. There people are so emotional, I get tired of it. ${ }^{30}$

In polarized national discourses, Estonian identity is constructed against the "Russian Other", "so that what the Estonians were, the Russians were not; what the Russians were, the Estonians were not” (Rausing 21). The personal memories of my interviewees however ran counter to this binary opposition between what is "Estonian" and what "Russian". In their recollections, Russian-speakers in Narva made use of experiences of difference in relation to Russia and Russians (as well as other Soviet Republics) contrasting their sense of place and self to their places of origin. The narratives thus indicate a greater diversity in place-making projects on the ground.

Significantly, the experiences of difference were not deriving from the presentday socioeconomic differences between the states but linked back to Soviet times and historic imaginations of the Baltic States as better places to live. Furthermore, the understanding of Narva as an Estonian town was institutionalized at the administrative level and perpetuated in the official discourse, symbols and local newspapers (on the two Soviet modes of institutionalizing ethnicity, the territorial and the personal, cf. Brubaker). Although in comparison to other localities Estonian language and other symbols of Estonianness were of minor significance in Narva, ${ }^{31}$ the level of the republic did matter in administrative terms as well as on the level of cultural representations. ${ }^{32}$ 
Russian-speakers adopted these discourses to frame Narva as an Estonian place and themselves as estonianized against the Russian “other”. In the case of one interviewee, who was born in Narva but obtained her professional education in Soviet Russia, the asserted cultural differences were so significant that she argued for the hardening of the present border regime to prevent more Russians from visiting Estonia. ${ }^{33}$ Although she had experienced personal limitations and a decline in her living-standard since the restoration of Estonian independence, in comparison to Russia and other places of origin, she felt that she was in a better situation. Distancing themselves from Russia, people like her could derive a "positive cultural association, even while living in a country where they may experience discrimination based on ethnic distinction” (Fein 343). It was a means of constructing belonging to Narva and to a space of higher cultural and economic development.

The narratives of Narva as an Estonian place raise our attention to the importance of older symbolic boundaries in Russian-speakers’ narratives. This doesn't mean that their memories of socialism exist as a "frozen past". On the contrary, what I have demonstrated is the dynamic relation between past and the present in processes of remembering where memories of the socialist past (among others the memories of boundaries between Soviet republics) are mobilized in diverse ways in the context of present-day experiences and needs.

\section{Conclusion: the Soviet past as a resource and limitation for making place}

"What time is this place?” ask Gelazis, Czaplicka and Ruble in their introduction to a volume on changing cultural landscapes in post-socialist cities. According to them, situating a place in history has become central for reimagining and remaking the cities of the former Soviet Union (1). The "time of a place” consequently tells us something about the kind of place it is, who belongs there and its orientation in the future. For the 
border town of Narva, there is no simple answer to this question. As a place with a multiply determined past, there are numerous historical reference points and territorial associations, and diverse ways of "making place”. In Estonian memory politics, the prewar past has been mobilized to distance oneself from the Soviet past and from Russia. Also on the local level, attempts to rewrite the mnemonic landscape in order to “integrate” Narva into Estonia and a wider European context could be clearly observed. In this article, I have chosen a perspective from below and focused on how people living in Narva make sense of the place they inhabit and how they negotiate the past in the light of shifting symbolic landscapes. Their personal narratives show that despite the devaluation by official political narratives, memories of the socialist past continue to be personally meaningful.

I have identified two narratives of place which are significant in the memory narratives of the local Russian-speaking population: people framed Narva on the one hand as a Soviet place linked to narratives of industrial work and post-war reconstruction and on the other, as an Estonian place, marked by economic and cultural superiority. Both spatial frames of Narva - as a Soviet town and as an Estonian town derive from memories of the socialist past and point to different mnemonic landscapes, which are shaped by Soviet histories of entanglements and connections between Narva and other places in the Soviet Union.

Borderlands are zones where the boundaries of place are particularly contested because of their "paradoxical character" (Baud and Schendel 216) as sites of difference and contact zones. The interviews show quite clearly that the inside and outside of a place are not simply imposed from above but that people living in the borderland shape and negotiate place by building upon previous experiences, discursive frames and older symbolic boundaries. Personal memories should not be ignored when studying shifts in 
symbolic geographies; for people living in the borderland they provide a resource in their meaning-making activities. As I have demonstrated, memories of the socialist past are used reflexively by people in the present-day context to counter the national narratives and negotiate their position as inhabitants of a marginal place. Remembering the past can serve both as a means of critique and reflection on the present - criticizing the form and results of the nationalization of the borderland - and can be used to reclaim belonging. In the life-story narratives this is done by stressing personal experiences linked to Narva, the contribution to the post-war reconstruction in Estonia as well as cultural differences to their places of origin.

In this article interviews have been used to give insights into memory work in a borderland and to show how the socialist past functions as a resource to express dissent and to (re)claim belonging. Similar ways of making sense of the past were observed in everyday encounters during my fieldwork and in other studies on Russian-speakers in Estonia. Ehala argues that the Bronze Soldier crisis in 2007 was a moment when Russianspeakers publically articulated their claim to cultural belonging in Estonia. While Estonian national narratives attempt to "uproot” Russian-speakers, they use memories of the Soviet past to reinscribe themselves in the local and national memoryscape.

Yet despite people’s imaginativeness in drawing upon the past, the "use value of the past” in the present is limited for constructing belonging. In present-day Estonia, Russian-speakers find themselves in a marginal position as the symbolic resources they have at their disposal have been delegitimized by the new rulers. It might be argued that remembering a different past would make a better resource for Russian-speakers to reclaim their belonging in Estonia. However, it is clear that people cannot simply choose what to remember. Personal memories can never be entirely instrumentalist as they remain linked to lived and embodied experiences. The personal accounts consequently 
reflect a tension: striving to belong and to find their place within the new symbolic geographies, Russian-speakers find themselves remembering and defending the socialist past which they experienced as meaningful.

\section{Acknowledgements}

I would like to thank Michael Pickering, Sabina Mihelj, Libora Oates-Indruchová, Pawas Bisht and the two anonymous reviewers for their helpful comments on earlier drafts of this paper.

\section{Notes}

1. For an overview cf. Troebst; Müller; Ebenshade.

2. By Russian-speakers I refer to ethnic Russians as well as to other ethnic groups, Ukrainians, Belorussians, Jews, etc. It has been argued that Russian language has become the marker for a new group identity in the Baltic States which is distinct from ethnic Estonians but which unites different ethnic groups and religions on the basis of a common language (Laitin).

3. There are apparent similarities to the German case and the asymmetric nature of the transition: In the face of the re-unification Eastern Germans didn't stay who they were but (to a greater extent than Western Germans) had to renegotiate the meaning of the past in order to adapt to present-day circumstances (cf. Berdahl; Glaeser). Likewise, Russian-speakers have been actively involved in making sense of the societal changes.

4. Such an approach builds upon recent works in geographical and anthropological theory which conceptualize places as contested and on-going constructions which do not have a homogeneous identity (exemplary works are Massey “Place, Space and Gender” and "For Space"; Gupta and Ferguson; Cresswell for a summary in the field of geography).

5. Cf. Onken "Memory and Democratic Pluralism" and Smith and Burch for notable exceptions which point into this direction.

6. In comparison to other places with multiply determined history, local politics of memory in Narva take place on a relatively small scale and have not really "heated up". Actors who are seriously interested in local history are few, which is reflected in the lack of literature on the subject. Unlike Tallinn and Tartu, there is no book publication offering a full account of Narva's history.

7. The interviewees did not form a homogeneous group but differed in their socioeconomic status, their educational level as well as political attitudes.

8. Interview with Evgenii, b. 1944, 08.11.2011 
9. Interview with Nadezhda, b. 1966, 18.01.2010

10. Interview with Elena, b. 1933, 09.11.2011

11. Interview with Svetlana, b.1951, 17.01.2010

12. Interview with Evgenii, b. 1944, 08.11.2011

13. Indeed, especially in the first post-war years, there was a constant lack of housing for the workers who came to Narva. In 1956 every inhabitant only had 5,3 squaremeters at his or her disposal (Konchenovskii 227) and also later people often had to wait for several years until they received a flat on their own.

14. Interview with Tamara, b.1955, 31.10.2011

15. Biographical research in Estonia has analysed in greater detail experiences of the transition (Aarelaid-Tart and Bennich-Björkman). In this context, Aarelaid-Tart has interpreted narratives of Russian-speakers as indicators for a "cultural trauma" in the making. Although cultural trauma might be a useful concept for characterizing the social classification of experiences of collective suffering, I think that the concept shouldn't be overextended by applying it equally to all ethnic groups in Estonia (Aarelaid-Tart). Using it to characterize the experiences of Russian-speakers disregards the social context and asymmetries in who qualifies as a trauma victim.

16. There is a range of sociological studies analyzing the status loss among Russianspeakers and the subsequent reconsideration of identities (for an early example cf. Laitin). Recently, scholars have analysed the differentiation within this group while at the same time pointing to the persistence of older mind-sets (Vihalemm and Kalmus, Lauristin and Heidmets).

17. Interview with Anton, b.1965, 25.10.2011

18. Interview with Mariya, b. 1943, 19.11.2011

19. Interview with Evgenii, b.1944, 08.11.2011; interview with Elena, b. 1933, 09.11.2011

20. Interview with Ekaterina, b. 1946, 10.10.2011

21. Interview with Sergei, b.1939, 13.10.2011

22. Interview with Ol'ga, b.1949, 22.01.2010

23. The supply situation and living standard in Narva was much better than in the places where most of the Russian-speaking newcomers came from. Also in the first post-war decade, when Estonia's North-eastern region was considered the least developed in the whole republic, people from Russia, Ukraine and Belorus moved there as WWII had left even greater destruction and famines in their former homes (Mertelsmann).

24. The Russian town of Ivangorod, which is located only across the bridge from Narva, used to form one social space with Narva sharing among others a public transportation system, canalization and water supply, and work places.

25. Interview with Svetlana, b.1951, 17.01.2010 
26. Interview with Anton, b.1965, 25.10.2011

27. Interview with Anton, b.1965, 25.10.2011

28. Interview with Anton, b.1965, 25.10.2011; interview with Tamara, b.1955, 31.10.2011; interview with Nina, b. 1972, 14.11.2011

29. Interview with Ekaterina, b. 1946, 10.10.2011

30. Interview with Tamara, b.1955, 31.10.2011

31. Tannberg, for example, states that after Stalin's death, Soviet inspectors who came to Narva criticized that too little attention was paid to Estonian national specificities and that the local party committee did use Estonian language in their political work (Tannberg).

32. In the official accounts, framing Narva as an Estonian town could even turn the relations between Narva and neighbouring Ivangorod in the RSFSR, both Russiandominated towns, into a "true embodiment of the friendship of the Soviet peoples" (Kann 264).

33. Interview with Nina, b. 1972, 14.11.2011

\section{References}

Aarelaid-Tart, Aili, Cultural Trauma and Life Stories. Helsinki: Kikimora Publications, 2006. Print.

Aarelaid-Tart, Aili and Li Bennich-Björkman. Baltic Biographies at Historical Crossroads. London, New York: Routledge, 2012. Print.

Ashwin, Sarah. Russian Worker: The Anatomy of Patience. Manchester: Manchester University Press, 1999. Print.

Batt, Judy, and Kataryna Wolczuk (ed.) Region, state, and identity in Central and Eastern Europe. London: Frank Cass, 2002. Print.

Baud, Michiel, and Willem van Schendel. "Toward a Comparative History of Borderlands.” Journal of World History 8.2 (1997): 211-242. Print.

Berdahl, Daphne. Where the World Ended. Re-Unification and Identity in the German Borderland. Berkeley, LA: University of California Press, 1990. Print.

Berg, Eiki, and Piret Ehin, eds. Identity and Foreign Policy. Baltic-Russian Relations and European Integration. Surrez, Burlington: Ashgate, 2009. Print.

Burch, Stuart, and David J. Smith. "Empty Spaces and the Value of Symbols: Estonia's 'War of Monuments' from Another Angle.” Europe-Asia Studies 59.6 (2007): 913-936. Print. 
Brubaker, Rogers. "Nationhood and the National Question in the Soviet Union and Post-Soviet Eurasia: An Institutionalist Account.” Theory and Society 23.1 (1994):47-78. Print.

Brüggemann, Karsten. “Der Wiederaufbau Narvas nach 1944 und die Utopie der ,sozialistischen Stadt'” Narva und die Ostseeregion : Beiträge der II. Internationalen Konferenz über die politischen und kulturellen Beziehungen zwischen Russland und der Ostseeregion. Ed. Karsten Brüggemann. Tartu Ulikooli Narva Kolledz: Narva, 2004. 81-103. Print.

Brüggemann, Karsten. “An 'Enemy’s Outpost' or 'Our West’? Some Remarks about the Discourse of Russian Pribaltika in the Russian Empire and the Soviet Union.“ Ethnic Images and Stereotypes - Where is the Border Line? Russian-Baltic Cross-Cultural Relations. Ed. Elena Nomm. Tartu Ulikooli Narva Kolledz: Narva, 2007. 81-98. Print.

Brüggemann, Karsten, and Andres Kasekamp. "The Politics of History and the "War of Monuments” in Estonia.” Nationalities Papers 36.3 (2008): 425-448. Print. Confino, Alon. “Collective Memory and Cultural History. Problems of Method.” American Historical Review 105. 2 (1997): 1386-1404. Print.

Cresswell, Tim. Place. A Short Introduction. Blackwell: Oxford, 2004. Print. Czaplicka, John, Nida Gelazis, and Blair A. Ruble, eds. Cities After the Fall of Communism. Reshaping Cultural Landscapes and European Identity. Washington: Woodrow Wilson Center Press, 2009. Print.

Ebenshade, Richard S. "Remembering to Forget: Memory, History, National Identity in Postwar East-Central Europe.” Representations 49 (1995): 72-96. Print.

Ehala, Martin. The Bronze Soldier. Identity Threat and Maintenance in Estonia. Journal of Baltic Studies 40.1 (2009): 139-158. Print.

Fein, Lisa C. "Symbolic boundaries and national borders: The construction of an Estonian Russian identity.” Nationalities Papers 33.3 (2005): 333-344. Print. Gelazis, Nida, Blair. A. Ruble, and John Czaplicka. "Introduction: What Time is this Place? Locating the Postsocialist City” Cities After the Fall of Communism. Reshaping Cultural Landscapes and European Identity. Ed. John Czaplicka, Nida Gelazis, and Blair A. Ruble. Washington: Woodrow Wilson Center Press, 2009. 1-13. Print.

Gieryn, Thomas F. “A Space for Place in Sociology.” Annual Reviews of Sociology 26.1(2000):463-96. Print. 
Gille, Zsusza, and Séan Ó Riain. “Global Ethnography.” Annual Review of Sociology 28 (2002), 271-79. Print.

Glaeser, Andreas. Divided in Unity. Identity, Germany, and the Berlin Police. Chicago, London: The University of Chicago Press, 1999. Print.

Gupta, Akhil and James Ferguson (ed.). Culture, power, place: explorations in critical anthropology. Durham and London: Duke University Press, 1997. Print.

Hackmann, Jörg, and Marko Lehti. "Introduction: Contested and Shared Places of Memory. History and Politics in North Eastern Europe.” Journal of Baltic Studies 39.4 (2008): 377-379. Print.

Halbwachs, Maurice. On Collective Memory. Chicago and London: University of Chicago Press, 1992. Print.

Hodgkin, Katherine, and Susannah Radstone. "Introduction: Patterning the National Past.” Contested Pasts. The Politics of Memory. Ed. Hodgkin, Katherine and Susannah Radstone. Abingdon: Routledge, 2003.169-174. Print.

Kaiser, Robert and Elena Nikiforova. "The performativity of scale: the social construction of scale effects in Narva, Estonia” Environment and Planning D: Society and Space 26.3 (2008):537 - 562. Print.

Kann, P.T. Narva. Stranicy istorii goroda. Tallinn: Izdatel'stvo Eesti Raamat, 1979. Print.

Kattago, Siobhan Ann. Memory and Representation in Contemporary Europe. The Persistence of the Past. Farnham, Burlington: Ashgate, 2012. Print.

Konchenovskii, Oleg. Narva. Gradostroitel'noe razvitie i arkhitektura. Tallinn: Valgus, 1991. Print.

Kuus, Merje. “'Those goody-goody Estonians': toward rethinking Security in the European Union Candidate States.” Environment and Planning D: Society and Space 22 (2004): 191-207. Print.

Laitin, David. Identity in Formation. The Russian-Speaking Populations in the Near Abroad. Ithaca and London: Cornell University Press, 1998. Print.

Lauristin, Marju and Mati Heidmets, ed. The Challenge of the Russian Minority. Emerging Multicultural Democracy in Estonia. Tartu: Tartu UP, 2002. Print.

Lehti, Marko, and David J. Smith, ed. Post-Cold War Identity Politics. Northern and Baltic Experiences. London, Portland Oregon: Frank Cass, 2003. Print. 
Lehti, Marko, Matti Jutila, and Markku Jokisipilä. “Never-Ending Second World War: Public Performances of National Dignity and the Drama of the Bronze Soldier.” Journal of Baltic Studies 39.4 (2008): 393-418. Print.

Light, Duncan and Craig Young. "Political Identity, Public Memory and Urban Space: a Case Study of Carol Park, Bucharest from 1906 to the Present.” Europe-Asia Studies 62.9 (2010): 1453-78. Print.

Massey, Doreen. Space, place, and gender. Minneapolis: University of Minnesota Press, 1994. Print.

Massey, Doreen. For space. London: Sage, 2005. Print.

Mälksoo, Maria. The Politics of Becoming European: A Study of Polish and Baltic PostCold War Security Imaginaries. London, New York: Routledge, 2010. Print.

Mertelsmann, Olaf. “Die Herausbilding des Sonderstatus der Nordostregion innerhalb der Estnischen SSR.” Narva und die Ostseeregion : Beiträge der II. Internationalen Konferenz über die politischen und kulturellen Beziehungen zwischen Russland und der Ostseeregion. Ed. Karsten Brüggemann. Tartu Ulikooli Narva Kolledz: Narva, 2004. 105-121. Print.

Misztal, Barbara A. Theories of Social Remembering. Maidenhead, Philadelphia: Open University Press, 2003. Print.

Müller, Jan-Werner, ed. Memory \& Power in Post-war Europe: Studies in the Presence of the Past. Cambridge: Cambridge University Press, 2002. Print.

Newman, David and Anssi Paasi. "Fences and neighbours in the postmodern world: boundary narratives in political geography.” Progress in Human Geography 22.2 (1998): 186 -207. Print.

Ochman, Ewa. "Municipalities and the Search for the Local Past: Fragmented Memory of the Red Army in Upper Silesia.” East European Politics and Societies 23.3 (2009): 392-420. Print.

Onken, Eva-Clarita. “The Baltic States and Moscow's 9 May Commemoration: Analysing Memory Politics in Europe.” Europe-Asia Studies 59. 1 (2007): 2346. Print.

Onken, Eva-Clarita. "Memory and Democratic Pluralism in the Baltic States: Rethinking the Relationship.” Journal of Baltic Studies 41. 3 (2010): 277-294. Print.

Paasi, Anssi. Territories, Boundaries and Consciousness. The Changing Geographies of the Finnish-Russian Border. Chichester: Wiley, 1996. Print. 
Prager, Jeffrey. Presenting the Past. Psychoanalysis and the Sociology of Misremembering. Cambridge, Massachusetts, London: Harvard University Press, 1998. Print.

Rausing, Sigrid. History, Memory, and Identity in Post-Soviet Estonia: The End of a Collective Farm. Oxford: Oxford University Press, 2004. Print.

Sahlins Peter. Boundaries: The Making of France and Spain in the Pyrenees. Berkeley: Univ. Calif. Press, 1989. Print.

Said, Edward W. “Invention, Memory, and Place.” Critical Inquiry 26 (2000):175-192. Print.

Schudson, Michael. “Lives, laws, and language: commemorative versus noncommemorative forms of effective public memory.” The Communication Review 2.1 (1997): 3-17. Print.

Smith, Anthony D. "Culture, Community and Territory: The Politics of Ethnicity and Nationalism.” International Affairs 72.3 (1996):445-458. Print.

Smith, David J. and Stuart Burch. "Enacting Identities in the EU-Russia Borderland. An Ethnography of Place and Public Monuments.” East European Politics \& Societies 26.2 (2012):400-424. Print.

Soja, Edward W. “The Spatiality of Social Life: Towards a Transformative Retheoretization.” Social Relations and Spatial Structures. Ed. Derek Gregory, and Urry John. Palgrave Macmillan, 1985, 90-127. Print.

Tannberg, Tõnu. “Der Kreml und die baltische Frage 1956.” Forschungen zur Baltischen Geschichte 2 (2007): 173-196. Print.

Taylor, Stephanie. “Identity Trouble and Opportunity in Women’s Narratives of Residence.” Auto/Biography 13 (2005): 249-265. Print.

Till, Karen E. "Places of Memory.” A Companion for Political Geography. Ed. John Agnew, Katharyne Mitchell, Gearoid O Tuathail. Oxford: Blackwell, 2003, 289301. Print.

Troebst, Stefan. “Jalta versus Stalingrad, GULag versus Holocaust. Konfligierende Erinnerungskulturen im größeren Europa.” Berliner Journal für Soziologie 3 (2005):381-400. Print.

Vihalemm, Triin and Veronika Kalmus. Cultural Differentiation of the Russian Minority. Journal of Baltic Studies 40.1 (2009): 95-119. Print.

Weiss-Wendt, Anton. Must-Valge Linn. Vana Narva Fotoajalugu. Tallinn 1997. Print. 
Zubkova, Elena Iur’evna. Pribaltika i Kreml'1940-1953. Moscow: Rosspen, 2008.

Print. 